\title{
Article
}

\section{Lifting the veil of depression and alcoholism in sport coaching: how do we care for carers?}

Roberts, Simon J., Baker, May, Reeves, Matthew, Jones, Gary and Cronin, Colum

Available at http://clok.uclan.ac.uk/25384/

Roberts, Simon J., Baker, May, Reeves, Matthew ORCID: 0000-0002-39032910, Jones, Gary and Cronin, Colum (2019) Lifting the veil of depression and alcoholism in sport coaching: how do we care for carers? Qualitative Research in Sport, Exercise and Health, 11 (4). pp. 510-526. ISSN 2159-676X

It is advisable to refer to the publisher's version if you intend to cite from the work. http://dx.doi.org/10.1080/2159676X.2018.1556182

For more information about UCLan's research in this area go to http://www.uclan.ac.uk/researchgroups/ and search for <name of research Group>.

For information about Research generally at UCLan please go to http://www.uclan.ac.uk/research/

All outputs in CLoK are protected by Intellectual Property Rights law, including Copyright law. Copyright, IPR and Moral Rights for the works on this site are retained by the individual authors and/or other copyright owners. Terms and conditions for use of this material are defined in the policies page.

\section{CLoK}

Central Lancashire online Knowledge www.clok.uclan.ac.uk

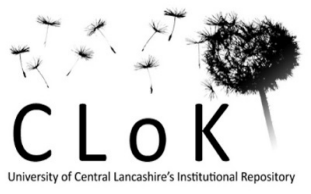


Lifting the veil of depression and alcoholism in sport coaching: how do we care for carers?

Lifting the veil of depression and alcoholism in sport coaching: how do we care for carers?

$\underline{\text { Simon J. Roberts }}{ }^{1}$, May Baker ${ }^{2}$, Matthew J. Reeves ${ }^{3}$ Gary Jones $^{2}$, \& Colum Cronin ${ }^{1}$

${ }^{1}$ Sport, Exercise and Pedagogy Research Group, Liverpool John Moores University, IM Marsh Campus, Barkhill Road, Liverpool, L17 6BD.

${ }^{2}$ School of Nursing \& Allied Health, Liverpool John Moores University, Tithebarn Street,

Liverpool, 2DT.

${ }^{3}$ Institute of Coaching and Performance, School of Sport, Health and Wellbeing, University of

Central Lancashire, Preston, Lancashire, PRI 2HE. 
1

12 Using the work of Goffman and Sartre, the story also alludes to how such symptoms can be hidden,

13 to greater and lesser extents, from professional colleagues. This is an important theoretical 14 contribution, because in order to care for coaches, colleagues, employers, and health professionals

\section{Abstract}

The purpose of this article is to explore the insights of an elite sport coach living with comorbid depression and alcohol misuse. Such consideration is necessary because as coaching is increasingly repositioned as a caring activity; the wellbeing of coaches themselves has rarely been considered. To address this gap, a narrative analysis methodology and a story telling approach was used to present the experiences of a case study coach (Steve). The story is derived from Steve's own perspective and the perspective of his wife, Jane. This novel multi-voiced approach reveals the complex interplay between the sporting environment, Steve's depression and his alcohol related problems. In doing so, Steve's story makes an original contribution by unveiling the issue of mental health in elite sport coaching. Steve's story depicts the significant impact of depressive symptoms, coupled by excessive alcohol use on a coach, their personal life, and their career. The will need to understand the needs of individuals such as Steve. Developing an open and supportive culture, which accepts that coaches are fallible, may however be a challenge within professional sport contexts.

18 


\section{Introduction}

In 2005, The Lancet published an essay by Kerry Mummery, a former American nationallevel swimming coach, surrounding the debilitating effects of depression in professional sport. Mummery's essay used the example of Kelly Holmes, a double Olympic gold medallist (athletics), to draw attention to depression in sport. Since this publication a number of high profile professional athletes have reported suffering from eomerbid alcohel misuse and mental ill healthmental illness, for example; Michael Slater, Marcus Trescothick, (cricket); Stan Collymore, Clarke Carlisle, Neil Lennon (soccer); and Ricky Hatton (boxing). Sadly, since 2005 there are also a number of reported deaths by suicide including; Robert Enke, Gary Speed (soccer), Wade Belak (ice hockey), Peter Roebuck, David Bairstow (cricket), Ray Easterling, Dave Duerson, Kendrick McKinley (American Football) (Malcolm \& Scott, 2012). More recently in the United Kingdom (UK)- we have witnessed a professional soccer coach reveal his experiences of living and working with a mental illness (i.e. Martin Ling) and sadly in 2017 Dermot Drummy a professional soccer manager $\underline{\text { committed suicide after losing his job at an English League club. }}$

Concomitantly, a small corpus of literature has argued that coaching should be (re)considered as a caring activity, where coaches care for athletes and their needs_Cronin,

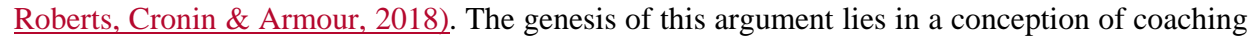
as a pedagogical activity (Jones, 2006; Armour, 2011). On this basis, it is has long been recognised that coaches have a legal duty of care, to safeguard participants (Partington, 2017). In practice, such care typically involves ensuring safe and reasonable training activities. In more recent times, however, authors have suggested that care should not be limited to the minimum legal requirement,

but that as a pedagogues, coaches should embrace a more aspirational and holistic caring ethic (Jones, 2009; Cronin \& Armour, 2017). From this perspective, a moral and social concern for the 
health, wellbeing and needs of athletes is a precursor to personalised, consensual and effective coaching practice. To that end, researchers have described how coaches in elite sport contexts could care for athletes. Specifically, it has been argued that coaches should listen to athletes' concerns and advocate for their needs (Knust \& Fisher, 2015), empathise and involve athletes in decision-making (Annerstedt \& Eva-Carin, 2014), and work with other staff such as medical professionals to develop a web of care around athletes (Cronin, Roberts, Cronin, \& Armour, 2018) (Cronin, Roberts, Cronin, \& Armour, In Press). Thus, through these guidelines, coaches are positioned as carers who are in-well placed to support and help athletes flourish as performers and individuals.

Notwithstanding, the positioning of coaching as a caring activity, the needs of coaches themselves and the care that they receive is an area that remains underdeveloped. This is remiss, because sport coaching in elite contexts can be a demanding and emotionally laborious activity. Indeed, instances of coaches experiencing burnout have been described (Frey, 2007; Olusoga, Butt, Hays, \& Maynard, 2009; Olusoga, Butt, Maynard, \& Hays, 2010; Bentzen, Lemyre, \& Kentta, 2015), and this has been linked to stress caused by the demands of the coaching role exceeding the capacity of the coach (Hjälm, Kenttä, Hassménan, \& Gustafsson, 2007). Specifically, coaches have described feelings of emotional exhaustion, low self-esteem, cynicism and sustained fatigue(Olusoga, Butt, Maynard, \& Hays, 2010). Symptoms that perhaps are in need of care. Thus, while coaches have been portrayed as potential carers, it is important to note that they themselves are vulnerable to poor mental healthmental illness. While the complexities of challenges such as depression and stress-alcohol dependency is becoming increasingly understood in athlete populations (Doherty, Hannigan, \& Campbell, 2016), the same cannot be said for that of
Field Code Changed

Field Code Changed

Formatted: Font: (Default) Times New Roman, 12 pt, Font color: Text 1, English (United Kingdom), Do not check spelling or grammar

Field Code Changed 
66 coachesthe ceach. In an attempt to fill this void, this paper reveals the debilitating nature of

67 depression in the life of an elite football (soccer) coach: Steve. Such research is necessary because

68 understanding the experiences of individuals in sport coaching is a valuable precursor to improving

69 those experiences (Jones, 2012). To that end, this paper presents a creative non-fiction narrative

70 of Steve's experiences of depression coupled with a deepening dependency on alcohol. In doing

71 so, the article makes an original contribution by highlighting how depression and alcohol dependency can manifest in the life of an elite sport coach. The contribution is significant because the health and wellbeing of practitioners does not only influence athletes' performance (Frey,

74 2007), but as Steve's story demonstrates, is an important factor in the both the working and

75 'hidden' personal lives of coaches and their family. Moreover, if coaching is to be positioned as a

76 sustainable caring activity, then coaches themselves may also need support in order to enact this

77 laborious and demanding role.

78

\section{Depression and Sport}

According to the Diagnostic Statistical Manual of Mental Disorders (DSM-V, 2013) individuals diagnosed with depression can experience a reduction in functioning while presenting a range of continuous symptomology. Contemporary understanding of the epidemiology of depression suggest those individuals affected will display somatic symptoms such as $\frac{;}{\dot{\xi}}$ sleep disturbance, weight and appetite changes, feelings of guilt or sadness, low levels of perceived self-worth, changes in libido/energy, poor concentration, and persistent thoughts of death and suicide (Doherty, Hannigan \& Campbell, 2016). Depression can be an incapacitating illness and is consequently regarded a major public health concern (Kull, Aninsaar, Kiive \& Raudsepp, 2012). The World Health Organisation (WHO) estimate that $151 \underline{322}$ million people worldwide suffer 
89 from depression, and a further 125 million people worldwide are reported to be affected by alcohol

90 related disorders (WHO, 20142Z). In both Western and non Western commmnities evidence

91 suggests that women are more likely to be diagnosed with depression than men (Bebbington,

92 1998). Recently however, there has been a reported increase in qualitative explorations of male

93 depression (Martin, Neighbors \& Griffith, 2013).

94 Interestingly, there is evidence suggesting that physical activity, sport and athletic exercise may

95 actively reduce bouts of depression and mental well-being in normative populations (i.e. Craft,

96 2005; Faulkner \& Biddle, 2004; Rethorst et al., 2009). However, it appears that athletes in elite

97 sport contexts may be more vulnerable to acute bouts of depression and associated mental health

98 problemsillness due to the intense challenge of striving for excellent performance (Carless \&

99 Douglas, 2009; 2012; 2013 Yang et al. 2007; Storch, Storch, Killiany, \& Roberti, 2005; Nixdorf,

100 Frank, \& Beckmann, 2013).

101

102 Of course,Elite -coaches similarly inhabit such intense contexts. Indeed, in elite sport, longevity

103 for the coach is often determined by performance related measures, and success and failure can

104 depend on small and erroneous margins (Olusoga, Butt, Maynard, \& Hays, 2010). For the coach

105 working in elite sport their ultimate goal is to improve athlete/team performance, to maintain high

106 win/loss ratios, and to push athletes to their limits. The coach is therefore often judged by the

107 performance(s) of the athlete(s) in their care. It is perhaps unsurprising therefore that professional

108 sport coaching is considered alongside other occupations such as teaching (Winefield \& Jarrett,

109 2001) and nursing (Pyrjmachuck \& Richards, 2007) as extremely stressful (Olusoga, Butt,

110 Maynard, \& Hays, 2010). From this position, it is reasonable to hypothesise that elite sport

111 coaches operate in environments that may not be conducive to positive mental health. 
113

114 to portray an ideal self-image, and then attempt to maintain the integrity of this image over time.

115 -Moreover, tThe masculine depression framework (Addis, 2008) suggests that traditional

conceptualisations associated with sport (i.e. competition, aggression, and toughness) can oftenlead men to display alternative depressive symptoms such as anger, self-destructive behaviour, gambling, substance abuse and womanising (Diamond, 2005). This framework is particularly relevant to elite sport environments such as professional football, which have been described as masculine, aggressive, authoritarian and uncaring (Cushion \& Jones, 2006; Thompson, Potrac, \& Jones, 2013; Roderick \& Schumacker, 2017). In such environments it is not surprising that coaches have been associated with impression management and 'putting on a front' that gains the respect of players and fellow staff (Potrac, Jones, \& Armour, 2002; Jones, Potrac, Cushion, Ronglan, \& Davey, 2011; Potrac, Jones, Gilbourne, \& Nelson, 2012).

$\underline{\text { Using dramaturgical metaphor Erving Goffman (1981) theorises that social actors often }}$ $\underline{\text { stage a performance to preserve 'face'. Put simply, Goffman's ideas of performativity suggest that }}$ 'virtual' identities are created as 'shows' where key moments of one's life are enacted in an attempt $\underline{\text { to persuade an audience that the actor has a social identity that is desirable for a given social context }}$

$\underline{\text { (Goffman, 1981, 1974). For example, a coach may 'perform' in an authoritative confident manner }}$ in order to conform to the stereotype of the infallible coach (Potrac, Jones, Armour, 2002).

Conversely, should an individual possess an attribute that is deemed incongruent to their role and context, then that individual is liable to be 'stigmatised' and 'discredited' (Goffman, 1963,p.13). $\underline{\text { For instance, a coach who experiences depression may be discredited, because depression is }}$ currently an attribute that is incongruent with the prevailing stereotype of the strong, stable, confident coach. Of course, in practice many coaches and athletes do experience depression, and
Commented [CC1]: Potrac, P., Jones, R., \& Armour, K. (2002). 'It's All About Getting Respect': The Coaching Behaviors of an Expert English Soccer Coach. Sport, education and society, 7(2), 183-202. doi.org/10.1080/1357332022000018869

Formatted: Font: 12 pt, English (United States)

Commented [CC2]: Goffman, E. (1963). Stigma: Notes on a spoiled identity. Jenkins, JH \& Carpenter.

Formatted: Font: 12 pt, English (United States) 
136 all are of course, fallible. Thus, the stereotype and stigma is not only inaccurate, but may be

137 dangerous because it could encourage individuals to "conceal their mental illness and perhaps

138 avoid support for fear of becoming 'discredited' (Goffman, 1963).- Thus $N$ Narrative accounts, such

139 as Steve's story (which follows below) are therefore warranted to a) challenge simplistic

140 conceptions of coaches as strong and infallible, and b) to better support those who may experience

141 depression. may actively reduce bouts of depression and mental well-being in normative populations (i.e.

144 Eraft, 2005; Fattkner \& Bidlle, 2004; Retherst et al., 2009). However, it appears that athletes in

Douglas, 2009; 2012; 2013 Yang et al. 2007; Storch, Storeh, Killiany, \& Roberti, 2005; Nixdorf, and failure can depend on small and erroneous margins (Olusoga, Butl, Maynard, \& Hays, 2010).

For the coach working in elite spert their ultimate goal is to improve athlete/team performance, to

maintain high win/loss ratios, and to push athletes to their limits. The coach is therefore often judged_, perhaps unfairly, by the performance $(s)$ of the athlete(s) in their care. It is perhaps

154 unsurprising therefore that professional sport coaching is considered alongside other occupations such as teaching (Winefield \& Jarrett, 2001) and nursing (Pyrjmachuck \& Richards, 2007) as extremely stressful (Olusega, Butt, Maynard, \& Hays, 2010). From this pesition, it is reasonable to hypothesise that elite sport coaches operate in environments that may not be conducive to positive mental health, and yet for coaches, acknowledging that they may suffer the symptoms of 


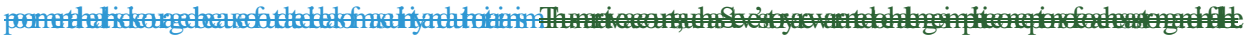

\section{Steve: Back story}

Steve (pseudonym) is currently in his mid-40s and has been known to (blinded) on a professional and personal basis for approximately 19 years. Steve and (blinded) first met whilst studying for undergraduate physical education degrees at a university in the United Kingdom (UK). Steve is a full-time, professional coach and he has worked with athletes from a number of well-known professional sporting organisations. being a very talented sportsman, he did not compete professionally for the sport for which he now coaches. Steve combined his early participation coaching roles with a full-time teaching position in a UK secondary school. In his early thirties Steve completed the highest coaching qualification offered by his National Governing Body (NGB) and had also attained a post-graduate qualification in Sports Therapy. This prompted a change in career as Steve was offered the opportunity to work full-time with young athletes in a performance environment. Steve enjoyed a number of successful years working with the younger athletes and was rewarded with two internal promotions. Fours year later Steve departed the UK to become the National Head Coach for an international sports association. However, following an unsuccessful attempt to qualify for a major international competition his contract was terminated and he returned with his wife and family to the UK. Steve is married to Jane (pseudonym) and they have a young familytwo young daughters. To his family, friends and colleagues he has the allure of a man with

180 the world at his feet. In the eyes of many, he has the ideal job and the perfect family. Steve's world 181 however, is a troubled one. He has been medically diagnosed with suffering from severe 


\section{Methodology}

A twice-told creative non-fiction methodology was utilized to examine Steve's experiences.

Twice-told narratives have a long history in literary circles, and have recently been advocated in qualitative research (Ellis, et al., 2018). Specifically, Ellis and colleagues (2018) demonstrated that examining experiences from multiple perspectives can positively influence meaning making, be more inclusive of other voices, lead to a more insightful collective conversation and prompt readers to consider care and empathy. Twice told narratives can also be consistent with the relativist ontology adopted herein, which sees reality as multiple, local and socially constructed. In addition, a creative non-fiction approach was utilized which involves basing research on empirical data e.g. interviews, yet presenting research in a manner that utilizes techniques associated with fictional literature such as developing character, scene and plot (O’Malley,

Winter, \& Holder, 2017). In doing so, researchers aspire to provide narratives that are grounded in data but enable readers to connect and understand multiple experiences (Smith, McGannon, \& Williams, 2016). The use of creative non-fiction in scholarly work is not new. Academics across various disciplines have made important contributions to often complex and sensitive topics by

200 allowing the reader to inhabit vicarious versions of reality of both the individual and the unique

201 (Carless \& Sparkes, 2009; Douglas \& Carless, 2008; Smith, 2013; Vickers, 2014a). Thus, in providing multiple perspectives and in utilizing creative non-fiction, the authors aspired to provide detail that would enable readers to use their own natural attitude to reflect upon their

204 own conceptions of mental health in sport coaching (Smith, 2018)(Smith B., 2018). 


\section{Participants}

Steve first contacted (blinded) via an email communication back in September 2012 following three years of intermittent personal correspondence. Three months after this initial contact, an informal, conversational face-to-face meeting with Steve was arranged (i.e. December, 2012). It was during this meeting that Steve revealed some of his anxieties, challenges, and ongoing problems for the first time, and planted the idea that I (blinded) write his story. Steve also revealed at this meeting that he had been keeping a diary of incidents, including his thoughts and feelings on an ad-hoc basis. Steve agreed to meet up on two further occasions, where he confirmed that he would share extracts from his diary to illustrate his understanding of his depressive episodes. In addition, Steve also consented to a series of reflexive, semi-structured interviews that commenced in March 2013 and ended in April 2016. It was agreed that Steve would decide on the number of interviews and the venue. In March 2015 during a scheduled meeting with Steve, he volunteered information that indicated his wife (Jane) also requested an opportunity to be interviewed, as she thought it would be interesting to hear what she referred to as 'her side of the story'. Steve was happy for Jane to be interviewed and a similar process of meetings took place with Jane, however it is worth noting both Jane and Steve were not interviewed at the same time.

\section{Ethical considerations}

The process of data collection prompted a number of ethical considerations and complex data collection issues. Firstly, (blinded) is not a mental health professional and voiced his concerns with Steve that the interview process in particular could make his illness worse. (blinded) therefore sought advice from a National Health Service (NHS) Consultant Psychiatrist, and recruited two established mental health academics (authors two and three) from within the university'sies own 
Nursing and Allied Health faculty to act as critical friends.

Prior to the first interview-taking place with Steve, a meeting was convened with the Consultant Psychiatrist, where a discussion around my interview technique and exemplar questions were was explored. Despite knowing Steve for several years the importance of gaining his trust were discussed. For instance, I was advised to monitor not only Steve's demeanour, but my own. The importance of making regular eye contact and nodding to indicate I was listening was encouraged. I was advised to avoid using my own professional jargon, and as someone who does not suffer with depression to avoid saying phrases such as, "I know exactly how you feel...". In contrast, I was encouraged to follow up broader questions such as (i) "Can you describe your symptoms of depression?"; with responses such as: "I can only imagine how difficult that must have been". In an attempt to allow the interview to flow with as little intrusion as possible I included simple, requests, such as "Can you please explain what you mean" or or "Tell me more about that". Importantly, I was reminded to be supportive but to avoid offering false generalisations in an attempt to offer reassurance, for example "I'm sure it will all be fine in the end".

Despite providing fully informed consent to the publication of their story, an on-going process of construction and negotiation was established with both Steve and Jane throughout the preparation of the manuscript. As the story of Steve unfolded, an ethical approach similar to that described by Phoenix (2010) was employed. In other words, regular consultations were conducted with Steve and Jane and written analyses were shared. Through this, Jane envisaged providing her alternative account of the experiences and this led to the twice-told methodology. Importantly, discussions took place at various stages of the study surrounding the possibility of the study being published, and whether Steve and Jane were happy for their story to be shared. Both Steve and 
Jane received a final version of the manuscript and despite some very minor historical errors provided consent for the paper to be considered for publication.

\section{Data capture and analysis}

Following institutional ethical approval, (blinded) embarked on a 21-month process of meeting and listening to Steve's story. During the period March 2013 - December 2016 Steve was interviewed on six separate occasions. All of the interviews were conducted face-to-face at locations decided by Steve and included his home and public places such as cafes. The longest interview was timed at 187 minutes, with the shortest being 128 minutes. The average time for each of the six interviews was approximately 174 minutes. The interviews with Jane commenced in 2016. Jane was interviewed on four occasions. The longest interview was timed at 67 minutes, with the shortest being 48 minutes.

Following the transcription of the 10 interviews, the dialogue was read and re-read until a manageable and visual representation of Steve's life experiences were compiled. A process of narrative analysis (Silverman, 2000) then followed in order to portray the voices of Steve and Jane in an attempt to capture his on-going struggles, via what Richardson (2002) referred to as a 'writing story'. Specifically, we_-selected Steve and Jane_s own words and selected key phrases and expressions with the aim of communicating his personal experiences of living with depression and his deepening dependency on alcohol. Evocative and emotional verbatim phrases as well as conversational expressions connected with Steve's personal experiences were then compiled to create what Caulley (2008) referred to as 'creative nonfiction'.

In-order-Tto capture an enhanced understanding of Steve and Jane's lives, during the writing and re-writing phase (Blinded) regularly shared the story with Steve and Jane to allow for 
the authentic representation of specific verbatim phrases and to ensure the reader was presented with a coherent, persuasive "emotional truth" (Miller \& Paola, 2005, p.83)interpretation of meaning (Riessman, 2008). During this phase of engineering the story, Steve and Jane offered some minor revisions to the text or introduced some corrections to the time-line of events. By allowing Steve and Jane the opportunity to become an active participant in the writing process we followed what Carless et al. (2014) described as a more ethically informed methodology. By welcoming Steve and Jane's multiple perspectives and suggestions during the construction of the storytelling component, the monolithic power relationship between researcher and participant was effectively reduced. As Franks (2010) suggests, researchers adopting dialogical research present themselves "primarily that of a witness, putting stories in dialogue with one another and then inviting...readers to enter this dialogue" (p.177). Advocates of creative non-fiction (i.e. Carless \& Sparkes, 2008; Douglas \& Carless, 2010; Carless et al., 2014) have repeatedly illustrated how this form of academic discourse encounters difficulties when applying more traditional forms of trustworthiness. This story therefore follows the guidelines outlined by Sparkes and Smith (2014, p.197) and Carless et al (2014, p.126).

- Worthy topic: The topic of research is relevant, timely, interesting, or evocative

- Meaningful coherence: Does the study achieve its goals and meaningfully interconnect literature, objectives, findings and interpretations with each other.

- Aesthetic merit: Do the creative nonfictions work, so the reader has a sense of completion in reading them. Do they invoke an interpretive response? Do they work?

- Evocation and illumination: Does the story work emotionally? Does the story illuminate a topic or individual? Does it shed light by defamiliarising an object or a process so that it can be viewed in a different way in which customary modes of perception operate? 
With these guidelines in mind, what follows is Steve's account.

\section{Steve}

\section{Failure not an option}

The second day of the training camp had drawn to an uncomfortable close - three days still to go. The heat and humidity was stifling, it was oppressive. Earlier during practice sweat had leaked from my body like a sprinkler system, soaking my T-shirt and shorts, it was like working in a sauna. Standing still in the baking sun was bad enough, but for the athletes who were working through their practice routines it was excruciating.

In contrast, the air-conditioning in my hotel room where I sought solace was cool and comforting. The hotel and training complex was five-star luxury. No expense had been spared. Truth be told, the evening was my favourite time of day. I couldn't be disturbed by anyone, least of all the athletes who with their vitality, arrogance and cockiness were making my life unbearable. There was a time when I enjoyed the banter and the horseplay. I used to encourage their voices into the practice session, but not anymore. I have come to realise that they are the prized assets, after all the organisation doesn't pay them to think, that's my job. Expectations are high. Failure was not an option, I had to deliver.

The only problem: I was in bits.

My mind and body had started to shut down. The symptoms were all too familiar. People think depression is about being sad all the time. Let me tell you it's not. For me it's the opposite of vitality, a lethargy that prevents any occupational functioning. The blackness that surrounded me was suffocating.

Looking back, I should have turned the position down, I was out of my depth. Despite my best efforts to hide it, I was in a really bad way. The darkness that consumed me was extinguishing 
my ability to function. My confidence should have been at an all-time high, but the reality was very different. I had this recurring fear of letting people down, it was killing me.

That evening I was agitated and restless. I had ordered dinner to my room but didn't eat anything. I picked up the phone and ten minutes later room service had taken away my tray, and replaced it with a bottle of scotch, no questions asked. After all, you would expect nothing more from a luxury five-star hotel. I opened the bottle and stood in front of one of the bedroom mirrors and raised a glass to myself.

My hands were shaking.

My heart was applauding itself.

The mirror however was no longer a friend. The gaunt, emaciated face that stared back was unrecognisable. I cut a lonely, pathetic figure. Confusion and fear were crouched behind my eyes. I stood in all my starkness, pleading, not for help, but for an explanation. The overhead light captured every unforgiving flaw.

\section{At that moment, I wanted to run. \\ At that moment, I wanted to hide. \\ At the moment, I wanted to die.}

For some unexplained reason I started to cry. The tears, which up until now had been contained behind a stoic dam of resistance, flowed. They cascaded down my face in torrents. It was difficult to breathe. My soul was drowning in a cocktail of booze and despair. I couldn't stop. I sat on the floor with my knees tucked up to my chin and sobbed and sobbed. I grabbed the bottle and poured the burnt orange liquid down my throat, again and again, until I got to the point where I gagged and could drink no-more.

The following morning, I woke to the sound of my phone buzzing. The display screen 
blinked back at me while my head pounded. I felt dreadful. I had a hangover of epic proportions.

My head was aching so much I thought it was going to explode. It took me all my energy to lift my head up from the pillow. The bed sheets were soaked with urine and perspiration. My throat had this burning sensation, and I needed to throw up.

I couldn't walk so I crawled on my hands and knees to the bathroom. The toilet was already full of bright orange vomit, but I had no recollection of how it got there. The smell was disgusting and I gagged once more, but threads of spit and whiskey smelling bile was all that I produced. I pushed two fingers down my throat, causing my whole body to shudder but nothing more came out. I crawled back into bed and picked up my phone.

\section{Jane's account}

\section{2 months later:}

\section{A Fresh Start}

I was pretending to be asleep when the alarm sounded. I watched Steve rise from the bed and walk gingerly across the floor rubbing his hand repeatedly across his forehead. I knew he was hungover. I had stepped downstairs in the night for a glass of water, and I had seen his pathetic, haphazard attempt to hide the empties in the recycling bin. I watched him open the door to our ensuite bathroom and stand in front of the mirror. The overhead light illuminated his reflection. The face in the mirror was unrecognisable to the man I fell in love with twenty-three years ago. His complexion revealed a life-time working outdoors exposed to the elements.

Sun, wind, and rain.

He looked old, too old for his years.

For a second I wanted to reach out to him and apologise for the argument the night before, but decided to keep my pretence up for a little longer. He closed the door, and turned on the shower. 
Despite the sound of water pounding the shower screens I could hear him retching into the sink, or was it the toilet basin? He was trying to disguise his illness again, but you need to understand, I had been here before.

I knew the signs.

My stomach tightened, and my heart pounded a little faster as I contemplated shouting out, “Steve, you OK in there?". I didn't of course, because something stopped me. I pulled the duvet around me and looked up at the ceiling, and wondered whether the suffering was at last coming to an end, for both of us.

It was twelve months since our disastrous venture abroad. Don't believe what was reported in papers. It was the breakdown he suffered during the training camp that was the real reason. Once back in the UK he promised me it would be different. He said it was under control and time to get back on the bike. He said it would be a fresh start.

In all fairness, he shouldn't have taken the job in the first place. The pressure was immense, and deep-down I don't think Steve was ready for a job of that magnitude, irrespective of whether he was in the right frame of mind, or not. This was his first appointment since returning home. He applied for loads vacancies on our return, but his old contacts had either moved on, or were ignoring his calls. I suspect it was the latter. I think word had leaked out.

He emerged in silence and got dressed into his training uniform. It was a sight that used to fill me with such pride, but not any longer.

He left the room without disturbing me.

Five-minutes later he closed the front door and he was gone.

\section{Steve's Words}

The wrong decision 
I left the house that morning under the false impression that I was going to work. The reality was very different. I had already called in sick. My head was pounding. There was no way I could function properly. Instead I drove to the local supermarket, bought two bottles of wine, drunk one and waited. Later, when I thought the alcohol was out of my system I started the engine. It turned out to be the wrong decision. legs to notice the flash of blue lights, or the intermittent whaling of the siren. The blind corners, short straights, the country lane was the perfect location for drinking in the car, because getting caught was almost impossible, but not today.

I pulled off the road, and rather clumsily positioned the car in a run-off area used by the local farmers and waited. It didn't take long before the police officer dressed in his luminous, high visibility jacket was tapping on the window.

"Can you turn the engine off for me please, sir?" he asked in a firm, but polite manner. "We've received reports from the supermarket that you were seen drinking alcohol inside your car, and I have reason to believe that you may have committed an alcohol related traffic offence.

I sat in silence. My mind racing.

"Have you been drinking, sir?" he asked, staring at the half-empty wine bottle lying beside me on the passenger seat.

Clearing my throat, I replied "Yes", before adding "I drink every day."

"In that case sir, please remove your seatbelt and escort me to my vehicle. I need to carry out a breath testing procedure."

He opened the rear door of his patrol car and I lowered myself onto the backseat. The black 411 leather upholstery was new, the interior polished and natural. The smell was pleasant, fast and 
clean. The aroma reminded me of a car dealership, redolent of varnished rosewood. The officer appeared oblivious to my presence as he reported the details of the offence into his hand-held police radio. An incongruous looking laptop computer was situated between the driver and passenger seat. He tapped away at the keypad, entering my responses to his questions: name, age, address, place of work. The next time I heard his voice it was instructing me, then showing me how to use the breathalyser machine: where to place my mouth, when to blow, how long to blow for.

I held my breath for a couple of seconds and blew hard into the transparent plastic tube. The machine lit up like a Christmas tree, all red.

He informed me that I have exceeded the legal limit of 35 microgrammes of alcohol in 100 millilitres of breath.

He told me I was under arrest for an alcohol related driving offence. I had no idea what would happen next.

\section{Jane}

\section{Living a death}

He clearly didn't hear the crunch of the tyres on the gravel, or the sound of the front door closing. He obviously wasn't expecting me home. I guess that's why he didn't have the time to hide the bottle, or sober up. As I stepped into our kitchen, I could tell by his confused expression, and the pitiful manner he pointed, open-mouthed in the direction of my car parked on the driveway, that the game was up. It didn't require much deduction to work out he was shitfaced. Although, I hadn't noticed his car was missing. 
on the balls of his feet with his arms extended out wide, wine glass perched in his hand.

"What the hell are you doing Steve?" I asked, snatching the glass off him, emptying what was left into the sink, before grabbing the neck of the bottle holding it up to the light. I glanced up at the clock on the wall. 'It's ten-thirty in the morning Steve, we've been here before. I told you last time. I don't intend going through that hell again."

Nobody spoke. Time momentarily, stood still.

I lifted my head and faced him, my tone was more conciliatory, the initial anger had begun to dissipate as the enormity of the situation started to sink in.

"Just a minute you're not dressed, and how come you're not at work?"

“I'm sorry, Jane. I'm so very sorry," he said. I was unsure whether he meant it or not, but it seemed genuine.

"What do you mean? You're not making any sense. What's happened?"

Another eerie, oppressive silence followed.

We stood staring at one another waiting for someone to make the first move. I wanted him to blurt it out, and take the initiative for once. Tell me what the hell was going on, but the explanation I craved so desperately was not forthcoming.

"It's happening again Steve. You told me this was going to stop, especially after the last time. Do you remember?"

In the end, I got the feeling he was left with no option. It was probably the booze swimming around his system that made the difference, because eventually he confessed.

He told me that he had been caught drink-driving.

At first I didn't know what to say. I was numb. In a state of shock. Here I was his wife, the mother of his children, the woman he supposedly loved but quite obviously no longer trusted, 
pleading for answers.

“Oh no, please tell me you're joking." I said, trying more than anything to convince myself that it wasn't true, and that's when the tears started to fall.

The silence returned, and then he lifted his head and said, "I'm not the man you married Jane.”

My hands touched his face.

"Love," I said, my lips trembling and more tears forming. "We've been here before, remember. You mean everything to me - to the kids - but..."

He wanted to push me away, I could tell. I could feel his body tense up. He was shutting down. At that moment, despite all the support I had given him over the years, I suddenly felt unimportant.

"I'm a fake Jane. It's all an act. Every day is about survival. You have no idea, you don't understand."

I was sobbing hard, my voice breaking under the strain.

"What you mean? You're making no sense."

"I told you."

"You told me I have no idea. You're beginning to worry me Steve."

I threw my arms around his shoulders and tried to embrace him. He stood cold, motionless, impervious to the warmth of my body.

"Every day is the same. It's about getting through it. It's difficult to explain and put into words..."

"Try me."

"I have these dark thoughts, all the time. It's torture. I don't have a life. I'm living a slow 
tortuous death. I want to shut myself away, and be on my own. There are days where I don't think

I can continue anymore. I want it to stop. I want to feel normal again. I want to go back to how I used to be."

I could feel the wetness of my cheeks against his face. He pattered me on the back, and that was when his own tears started to fall.

\section{Steve}

\section{Running on empty}

Standing on the station platform drained, exhausted, and running on empty I couldn't help but wonder, why. The questions that reverberated inside my mind, the answers I hadn't the energy to chase anymore, had finally taken their toll. Moments earlier I had used Jane's car to drive to the station. I did it without thinking. I wasn't bothered about the driving ban my life was in ruins. Jane's words from the night before danced around in my head:

I'm leaving you Steve...

We can't carry on like this anymore...

I want a divorce...

It was the final blow to a fragile and tormented mind.

The platform was deserted. I had only the electronic arrival screen and the automated recordings, reminding me to stand behind the yellow line, for company. My mind wandered and I imagined how earlier in the day the platform would have been occupied with unenthusiastic looking commuters, standing shoulder to shoulder, about to embark on their short journey to the city, and the beginning of another working day. A digital clock suspended next to the passenger information screen told me the next train was on time and would arrive at platform two in six minutes. I checked my phone. Ten missed calls from work. Two calls from Jane. 
They would get over it.

For the first time in months, no years, I had absolute clarity. The darkness that had suffocated me for so long was at last allowing me to breath. I don't think you could call it an epiphany, but I felt light headed and despite not touching a drop I felt intoxicated with feelings of sudden relief and satisfaction.

My mind was made up.

A decision had been reached.

I was satisfied, it was the right one.

The platform clock said five minutes.

With the exception of the movement of some nearby trees all around me was quiet. There was a stillness in the air. It was as though nature had afforded me one final period of tranquil contemplation.

The platform clock said three minutes.

I decided it was time and started to walk down the platform in the direction of the levelcrossing, which was located about 200 yards from where I was standing. The only sound my heart pounding. I shouted out Jane's name, but of course she couldn't hear.

Another quick glance confirmed the platform was still empty, and in the distance I could see the outline of the train. It was difficult to establish whether the train was actually moving or slowing down. In the end it was the discernible change in the sound of the engine, which provided the evidence that the train was beginning to decelerate. I carried on walking. The platform clock said one minute.

The next thing I heard was the hissing sound of air escaping, an engine ticking over. The hydraulic sound of doors opening confirmed the train was stationary. I looked back again and 
watched a small number of passengers alight the train. They were too busy tapping away at their mobile devices to notice my presence.

The gate for accessing the level-crossing was ahead of me, a distance of less than 50 yards. A sign informed me of the danger of crossing a live railway track. There was another sign, which caught my attention. The text was white, printed on a lime green coloured background and caused me to stop, an ironic smirk crossed my face.

If things are getting to you call Samaritans: 0800909090.

I knew the train would not be travelling at full speed by the time it reached the crossing, but it would be quick enough.

The shrill of the guard's whistle.

I pictured the guard pushing together the buttons and the closing of the passenger doors. I looked up to the sky and imagined what the impact would feel like. I thought about the driver and the passengers, aware my actions had ramifications beyond that of my immediate family and friends.

The train was leaving the platform.

I pushed the automatic button to activate the electronic gate but to my frustration it remained locked. I attempted to release it by using the metal latch, but it did not budge. The train was beginning to accelerate. I heard the sound of the clumps and clatter of metal on metal and the expansion of the track, the whine of the motors as it approached the crossing at a speed which would prevent any possibility of the train stopping in time. I realised that my window of opportunity was diminishing with every second that passed. I placed both my hands on the top of the wooden gate and hurled up my legs. Throwing one leg on top of the gate, I countered the force required by pushing my standing leg off from the ground. My efforts were rewarded. 
I was in position.

I jumped down but lost my balance, falling backwards and landed against the gate. I couldn't look at my intended target. I was concerned I may see the face of the driver. Rather cowardly, and somewhat selfishly, I decided that I didn't want the face of a complete stranger to be my final image on this earth.

I heard the sound of the train horn.

Had the driver spotted me?

What was he thinking?

Was he thinking of applying the emergency break?

I took a step forward and sank to my knees. All around me there was an explosion of noise. With an exhilarating force the train hurtled past. The force of the wind pushed into my cheeks as the carriages accelerated by one by one. I felt no pain. There was no impact.

I looked up and caught a glimpse of the guard.

Our eyes met.

He stared back at me.

I could tell by the look of horror on his face, he knew exactly what I was intending to do.

\section{A Brief Discussion: Impression Management, Stigma and Shame.}

From a coaching perspective, the narrative reveals turbulent and heart wrenching events that occurred in hotel rooms, in Steve's car, and in Jane and Steve's home. These events are juxtaposed with the professional image that Steve aspired to portray in his formal coaching tracksuit and even at home by 'hiding bottles'. Indeed, Steve eventually characterises himself as 'a fake' because 
572 'itsit's all an act'. Moreover, Steve's 'professional front' is crystalised in Jane's summation of their 573 time working abroad;

Don't believe what was reported in papers. It was the breakdown he suffered during the training camp, that was the real reason.

576

a) A full cover and concealment from everyone.

b) Removing themseleves from a social context e.g. by moving house, jobs or friendship group.

c) Discrete disclosure to individuals in certain parts of one's life e.g. family or health care professionals, but not work.

d) Discrete diclosure to individuals at work in powerful positions such as those at the top of a hierarchy.

e) Discrete disclosure to individuals with similar atrributes e.g. mental health support groups.

f) Allocating the signs of one stigmatised attribute (e.g. mental illness) to another cause (e.g. fatigue).

g) Full disclosure as a means of confronting the attribute and seeking support.

588 In Steve's case, he "manages crucial information" in order to present a socially acceptable front

589 to his employer (Goffman, 1963, p. 115). In doing so, Steve manages to conceal his mental illness.

590 which in elite coaching could be construed as a 'shameful' attribute. Indeed, Jane's additional

591 voice is particuarly useful in this study because it illumnates some of Steve's back stage 592 experiences. 

be why he calls in sick before settting off for work. This may be why he clumsily hides bottles from Jane, and may be why he listens out for Jane's car on the gravel. It is, however, understandable that Steve should not want others to see his struggle. This is because apart from feelings of shame, he also inhabits a world of high expectations, and ef arrogant and cecky footballersone in which he considers mental illness to be a stigmatising concept. If word 'leaks out', then his future employment is at risk. Paradoxically however, the more effectively that Steve hides-impression manages his depression and alcohol dependence (in a back stage area), then the less likely he is to receive the care and support that he needs. Thus, Steve's experiences have significant implications for those who seek to care for coaches with mental health challengesillness. Firstly, it suggests that coaches who need support may deliver a confident and coherent front stage performance. Therefore, employers, and fellow staff may need training in order to recognise the subtle signs and symptoms of poor mental health. More specifically, while others have correctly called for coaches to provide repeated attention to the needs of athletes (Annerstedt \& Eva-Carin, 2014), Steve and Jane's narrative illustrates that employers may need to ensure that they also afford sustained attention to the care needs of coaches themselves. Secondly, comfortable asking for support and a culture which envelopes them in a web of care (Cronin, Roberts, Cronin, \& Armour, In Press)(Cronin, Roberts, Cronin \& Armour, 2018).: To that end,

613 perhaps the listening recommended by Knust and Fisher (2015), empathy advocated by Annerstedt 614 and Eva-Carin (2014) and medical support suggested by Cronin, Roberts, Cronin, and Armour 615 (2018In Press) should not be confined to athletes but also extended to coaches themselves. 
This study provides a voiced understanding of the meanings that affect an elite sport coach

617 suffering with severe depression and a deepening dependancy on alcohol. However, this study also

contains some methodological limitaions which need to be acknowledged. First, the narrative was produced by an indiviudal currently living in the UK, thus experiences of navigating mental health

issues may not be indicative of those living outside this region. Second, as our participant was not

engaged in any help-seeking process, our study is unable to offer any targated interventions surrounding the experiences of the illness during treatment. Third, despite our best efforts to depict $\underline{\text { Steve's suffering through his choice of words and language, we accept that every word caries }}$ sequence of events leading up to Steve's illness.

\section{Conclusion} and relationships. Moreover, we hope to prompt readers to consider their own work places, their

630 own mental health, and that of their colleagues. On this topic, we wonder if sports organisation's and agencies are doing enough to support coaches and their mental wellbeing? What systems are in place to support a coach's mental wellbeing? Coaches use techniques to develop and maintain their athlete's mental wellbeing, however, coaches do not appear to be able to access or receive these techniques from their employers themselves. Further non-fiction narrative studies into athlete's/organisations perceptions of (1) mental health and whether this affects their relationship with their coach and (2) whether mental health affects a coach's ability to work effectively in a competitive sporting arena may aid in developing awareness that can break down barriers for help 
639 and well-being in coaches and athletes in the sporting world and facilitate further understanding of

640 the role of mental health within this specific area.

642 Aside from simply highlighting the debilitating nature of Steve's mental health problems, and his 643 deepening dependency on alcohol, Steve's experience begin the process of lifting the veil of 644 secrecy and silence, which currently surrounds depression and alcohol related disorders in professional coaching. The story has shed light on the stigma surrounding mental illness in sport,

646 and the shame that coaches may experience. It is our contention that Steve's story is not unique, 647 and it may well be that there are a number professional coaches working in elite sport, who are suffering similar depressive symptoms, coupled by excessive alcohol use. However, until the

649 culture within professional sport changes, and coaches like Steve feel compelled to speak out, then

650 future research will be limited. It is envisaged that the story presented will offer an opportunity to

651 develop more thought-provoking and critical discussion and advance our understanding of mental

652 illness in sport.

653 Acknowledgements

654 The authors would like to thank both Steve and Jane for sharing their story and for allowing us

655 the opportunity to share their story with you. The authors would also like to acknowledge two

656 very helpful and supportive reviewers whose comments on earlier drafts helped improve the

657 quality of the final version. 
Addis, M.E. (2008). Gender and depression in men. Clinical Psychological Science Practice, 15(3), 153-168.

American Psychiatric Association (2013). Diagnostic and Statistical Manaual of Mental Disorders (DSM-IV-TR), $5^{\text {th }}$ Edn. Washington, DC: American Psychiatric Association.

Annerstedt, C., \& Eva-Carin, L. (2014). Caring as an important foundation in coaching for social sustainability: a case study of a successful Swedish coach in high-performance sport. Reflective Practice, 15(1), 27-39. doi:10.1080/14623943.2013.869204

Armour, K. M. (2011). Sport pedagogy: An introduction for teaching and coaching (1 ed.). London: Routledge.

Bentzen, M., Lemyre, P.-N., \& Kentta, G. (2015). Changes in Motivation and Burnout Indices in High-Performance Coaches Over the Course of a Competitive Season. Journal of Applied Sport Psychology, 1-21. doi:10.1080/10413200.2015.1053160

Carless, D., \& Douglas, K. (2009). 'We haven't got a seat on the bus for you' or 'all the seats are mine': narratives and career transition in professional golf. Qualitative Research in Sport, Exercise and Health, 1, 51-66.

Carless, D., \& Douglas, K. (2012). Stories of success: cultural narratives and personal stories of elite and professional athletes. Reflective Practice, 13, 387-398.

Carless, D., \& Douglas, K. (2013). Living, resisting, and playing the part of athlete: narrative tensions in elite sport. Psychology of Sport and Exercise, 14, 701-708.

Carless, D., \& Sparkes, A. C. (2008). The physical activity experiences of men with serious mental illness: Three short stories. Psychology of Sport and Exercise, 9(2), 191-210. http://doi.org/10.1016/j.psychsport.2007.03.008

Carless, D., Sparkes, A. C., Douglas, K., \& Cooke, C. (2014). Disability, inclusive adventurous training and adapted sport: Two soldiers' stories of involvement. Psychology of Sport and Exercise, 15(1), 124-131. http://doi.org/10.1016/j.psychsport.2013.10.001

Connaughton, D., Wadey, R., Hanton, S., \& Jones, G. (2008). The development and maintenance of mental toughness: Perceptions of elite performers. Journal of Sports Sciences, 26(1), 8395. http://doi.org/10.1080/02640410701310958

Corrigan, P. (2004). How stigma interferes with mental health care. American Psychologist, 59(7), 
Craft, L. L. (2005). Exercise and clinical depression: Examining two psychological mechanisms. Psychology of Sport and Exercise, 6(2), 151-171.

Cronin, C., \& Armour, K. M. (2017). 'Being' in the coaching world: New insights on youth performance coaching from an interpretative phenomenological approach. Sport, Education and Society, 22(8), 919-931. doi:10.1080/13573322.2015.1108912

Cronin, C., Roberts, S., Cronin, O., \& Armour, K. (In Press). Julie's Story; Caring For, and With Others. In C. Cronin, \& K. Armour, Care in Sport Coaching: Pedagogical Cases. London: Routledge.

Cushion, C., \& Jones, R. (2006). Power, discourse and symbolic violence in professional youth soccer:the case of Albion FC. Sociology of Sport Journal, 23(2), 142-161. doi:10.1123/ssj.23.2.142

Diamond, J. (2005) The Irritable Male Syndrome: Understanding and managing the 4 keycauses of depression and aggression. Emmaus, PA: Rodale Books.

Douglas, K., \& Carless, D. (2008). Using stories in coach education. International Journal of Sports Science and Coaching, 3(1), 33-49

Douglas, K., \& Carless, D. (2010). Restoring connections in physical activity and mental health research and practice: A confessional tale. Qualitative Research in Sport and Exercise, 2(3), 336-353. http://doi.org/10.1080/19398441.2010.517039

Field Code Changed

Ellis, C., Bochner, A., Rambo, C., Berry, K., Shakespeare, H., Gingrich-Philbrook, C., . . . Bolen, D. M. (2018). Coming Unhinged: A Twice-Told Multivoiced Autoethnography. Qualitative Inquiry, 24(2), 119-133. doi:10.1177/1077800416684874

Faulkner, G., \& Biddle, S. J. H. (2004). Exercise and depression: Considering variability and contextuality. Journal of Sport \& Exercise Psychology, 26(1), 3-18.

Frey, M. (2007). College coaches' experiences with stress - "problem solvers" have problems, too. The Sport Psychologist, 21(1), 38-57. http://doi.org/10.1123/tsp.21.1.38

Hjälm, S., Kenttä, G., Hassménan, P., \& Gustafsson, H. (2007). Burnout among elite soccer coaches. Journal of Sport Behavior, 30(4), 415-427.

Jones, G. (2002). What is this thing called mental toughness? An investigation of elite sport performers. Journal of Applied Sport Psychology, 14(3), 205-218.

Jones, G., Hanton, S., \& Connaughton, D. (2007). A framework of mental toughness in the world's best performers. The Sport Psychologist, 21(2), 243-264. 
Jones, R. (2012). Editorial. Sports Coaching Review, 1(1), 1-3.

Jones, R. L. (2006). The Sports Coach as an Educator: Re-conceptualising Sports Coaching (1 ed.). London: Taylor and Francis.

Jones, R. L. (2009). Coaching as caring (the smiling gallery): accessing hidden knowledge. Physical Education and Sport Pedagogy, 14(4), 377-390. doi:10.1080/17408980801976551

Jones, R. L., Potrac, P., Cushion, C., Ronglan, L., \& Davey, C. (2011). Erving Goffman: interaction and impression management, playing the coaching role. In R. Jones, P. Potrac, C. Cushion, \& L. Ronglan, The Sociology of Sports Coaching (pp. 15-27). London: Routledge.

Jowett, S., \& Cockerill, I. (2003). Olympic medalists' perspective of the athlete-coach relationship. Psychology of Sport and Exercise, 4(4), 313-331.

Knust, S. K., \& Fisher, L. A. (2015). NCAA Division I Female Head Coaches' Experiences of Exemplary Care Within Coaching. International Sport Coaching Journal, 2(2), 94-107. doi:10.1123/iscj.2013-0045

Kull, M., Ainsaar, M., Kiive, E., \& Raudsepp, L. (2012). Relationship between low depressiveness and domain specific physical activity in women. Health Care for Women International, 33(5), 457-472. http://doi.org/10.1080/07399332.2011.645968

Field Code Changed

Lee, K. M., Xie, H., \& Parasuram, R. (2014). The effects of psychoeducation on patients with schizophrenia and their families: An integrative review. Singapore Nursing Journal, $41(2), 3-16$.

Lucksted, A., McFarlane, W., Downing, D., \& Dixon, L. (2012). Recent developments in family psychoeducation as an evidence-based practice. Journal of Marital and Family Therapy, 38(1), 101-121. http://doi.org/10.1111/j.1752-0606.2011.00256.x

Field Code Changed

Malcolm, D., \& Scott, A. (2012). Suicide, sport and medicine. British Journal of Sports Medicine, 46(16), 1092-1093. http://doi.org/10.1136/bjsports-2012-090974

Field Code Changed

Markser, V. Z. (2011). Sport psychiatry and psychotherapy. Mental strains and disorders in professional sports. Challenge and answer to societal changes. European Archives of Psychiatry and Clinical Neuroscience, 261(S2), 182-185. http://doi.org/10.1007/s00406011-0239-x

Mechanic, D., Bilder, S., \& McAlpine, D. D. (2002). Employing persons with serious mental illness. Health Affairs, 21(5), 242-253. http://doi.org/10.1377/hlthaff.21.5.242

Field Code Changed 
Mellalieu, S. D., Hanton, S., \& Fletcher, D. (2006). A competitive anxiety review: Recent directions in sport psychology research. In S. Hanton \& S. D. Mellalieu (Eds.), Literature reviews in sport psychology (pp. 1-45). Hauppauge, NY: Nova Science.

Möller-Leimkühler, A. M. (2002). Barriers to help-seeking by men: A review of sociocultural and clinical literature with particular reference to depression. Journal of Affective Disorders, 71(1-3), 1-9. http://doi.org/10.1016/S0165-0327(01)00379-2

Mummery, K. (2005). Essay: Depression in sport. The Lancet, 366 (Special issue), S36-S37. http://doi.org/10.1016/S0140-6736(05)67840-3

National Institute for Clinical Excellence (NICE). (2009). Depression in adults: The treatment and management of depression in adults. Retrieved October 25, 2016, from https://www.nice.org.uk/guidance/CG90

National Institute for Health and Clinical Excellence (NICE). (2011). Alcohol-use disorders, diagnosis, assessment and management of harmful drinking and alcohol dependence. Retrieved October 25, 2016, from https://www.nice.org.uk/guidance/CG115

Nixdorf, I., Frank, R., \& Beckmann, J. (2016). Comparison of athletes' proneness to depressive symptoms in individual and team sports: Research on psychological mediators in junior elite athletes. Frontiers in Psychology, 7(893). http://doi.org/10.3389/fpsyg.2016.00893

Olusoga, P., Butt, J., Hays, K., \& Maynard, I. (2009). Stress in elite sports coaching: Identifying stressors. Journal of applied sport psychology, 21(4), 442-459. doi:10.1080/10413200903222921

Olusoga, P., Butt, J., Maynard, I., \& Hays, K. (2010). Stress and coping: A study of world class coaches. Journal of Applied Sport Psychology, 22(3), 274-293. http://doi.org/10.1080/10413201003760968

O’Malley, L., Winter, S. \& Holder, T. (2017) 'Always picking country over club': a creative non-fiction story of an international coach-athlete-coach triad. Qualitative Research in Sport, Exercise and Health, 10(2), 223-237.

Partington, M., \& Cushion, C. J. (2012). Performance during performance: using Goffman to understand the behaviours of elite youth football coaches during games. Sports Coaching Review, 1(2), 93-105. doi:10.1080/21640629.2013.790167

\section{Partington, M. (2017). Sports coaching and the law of negligence: implications for coaching} practice. Sports Coaching Review, 6(1), 36-56

Phoenix, C. (2010). Auto-photography in aging studies: Exploring issues of identity construction in mature bodybuilders. Journal of Aging Studies, 24(3), 167-180. http://doi.org/10.1016/j.jaging.2008.12.007
Field Code Changed

Field Code Changed

Field Code Changed

Field Code Changed

Field Code Changed 
Pierce, D., Liaw, S.-T., Dobell, J., \& Anderson, R. (2010). Australian rural football club leaders as mental health advocates: An investigation of the impact of the Coach the Coach project. International Journal of Mental Health Systems, 4(1), 10. http://doi.org/10.1186/1752-4458-4-10

Potrac, P., Jones, R. L., Gilbourne, D., \& Nelson, L. (2012). 'Handshakes, BBQs, and bullets': selfinterest, shame and regret in football coaching. Sports Coaching Review, 1(2), 79-82. doi:10.1080/21640629.2013.768418

Potrac, P., Jones, R., \& Armour, K. (2002). It's All About Getting Respect': the coaching behaviors of an English soccer coach. Sport, Education and Society, 7(2), 183-202. doi:10.1080/1357332022000018869

Powers, M. B., Vedel, E., \& Emmelkamp, P. M. G. (2008). Behavioral couples therapy (BCT) for alcohol and drug use disorders: A meta-analysis. Clinical Psychology Review, 28(6), 952-962. http://doi.org/10.1016/j.cpr.2008.02.002

Pryjmachuk, S., \& Richards, D. A. (2007). Mental health nursing students differ from other nursing students: Some observations from a study on stress and coping. International Journal of Mental Health Nursing, 16(6), 390-402. http://doi.org/10.1111/j.14470349.2007.00494.x

Rethorst, C.D., Wipfli, B.M. \& Landers, D.M. (2009). The antidepressive effects of exercise. Sports Medicine, 39, 491-511.

Riska, E., \& Ettorre, E. (1999). Mental distress: Gender aspects of symptoms and coping. Acta Oncologica, 38(6), 757-761. http://doi.org/10.1080/028418699432914

Roderick, M., \& Schumacker, J. (2017). "'The whole week comes down to the team sheet': a footballer's view of insecure work.". Work, employment and society, 31(1), 166-174. doi:10.1177/0950017016672792

Rodgers, M. L., Strode, A. D., Norell, D. M., Short, R. A., Dyck, D. G., \& Becker, B. (2007). Adapting multiple-family group treatment for brain and spinal cord injury intervention development and preliminary outcomes. American Journal of Physical Medicine \& Rehabilitation, 86(6), 482-492. http://doi.org/10.1097/PHM.0b013e31805c00a1

Roorbach, B. (2008). Writing life stories: How to make memories into memoirs, ideas into essays, and life into literature. Cincinnati, OH: Writer's Digest Books.

Sartre, J.-P. (1943/1984). Being and nothingness. (H. E. Barnes, Trans.) New York: Washington Square Press

Scheid, T. L., \& Suchman, M. (2001). Ritual conformity to the Americans with disabilities act: Coercive and normative isomorphism. In S. W. Hartwell \& R. K. Schutt (Eds.), Research in Social Problems and Public Policy (Volume 8) (pp. 105-140). Bingley: Emerald.
Field Code Changed

Field Code Changed

Field Code Changed

Field Code Changed 
862

Silverman, D. (2000). Analyzing talk and text. In N. K. Denzin \& Y. S. Lincoln (Eds.), Handbook of Qualitative Research (pp. 821-834). Thousand Oaks, CA: Sage.

Smith, B. (2013). Sporting spinal cord injuries, social relations, and rehabilitation narratives: an ethnographic creative non-fiction of becoming disable though sport. Sociology of Sport Journal, 30(2), 132-152.

Smith, B. (2018). Generalizability in qualitative research: misunderstandings, opportunities and recommendations for the sport and exercise sciences. Qualitative Research in Sport, Exercise and Health, 137-149. doi:10.1080/2159676X.2017.1393221

Smith, B., McGannon, K. R., \& Williams, T. L. (2016). Ethnographic creative non-fiction: exploring the what's, why's and how's. In G. Molnar, \& L. Purdy, Ethnographies in Sport (pp. 59-72). Abingdon: Routledge.

Sparkes, A. C. (1996). The fatal flaw. Qualitative Inquiry, 2(4), 463-494

Sparkes, A.C. (2007). Embodiment, academics, and the audit culture: a story seeking consideration. Qualitative Research, 7, 521.

Sparkes, A. C., \& Smith, B. (2014). Qualitative research methods in sport, exercise and health: From process to product. London: Routledge.

Storch, E. A., Storch, J. B., Killiany, E. M., \& Roberti, J. W. (2005). Self-reported psychopathology in athletes: A comparison of intercollegiate student-athletes and nonathletes. Journal of Sport Behavior, 28(1), 86-98.

Vickers, M.H. (2014a). Workplace bullying as workplace corruption: a creative writing higher education case study. Administration and Society. 46(8), 960-985.

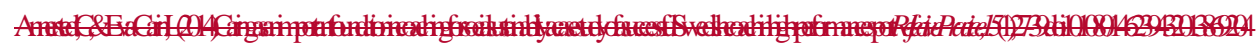
Wilkins.

Vogel, D. L., Wade, N. G., \& Haake, S. (2006). Measuring the self-stigma associated with seeking psychological help. Journal of Counseling Psychology, 53(3), 325-337.

Vogel, D. L., Wade, N. G., \& Hackler, A. H. (2007). Perceived public stigma and the willingness to seek counseling: The mediating roles of self-stigma and attitudes toward counseling. Journal of Counseling Psychology, 54(1), 40-50. http://doi.org/10.1037/0022-0167.54.1.40

Field Code Changed

Whisman, M. A., \& Beach, S. R. H. (2012). Couple Therapy for Depression. Journal of Clinical Psychology, 68(5), 526-535. http://doi.org/10.1002/jclp.21857 
908

909

910

911

912

913

14
WHO. (2014). Depression: A global crisis. Retrieved October 25, 2016, from http://www.who.int/mental_health/management/depression/wfmh_paper_depression_wmhd 2012.pdf

Winefield, A. H., \& Jarrett, R. (2001). Occupational stress in university staff. International Journal of Stress Management, 8(4), 285-298. http://doi.org/10.1023/A:1017513615819

Yang, L. H., Kleinman, A., Link, B. G., Phelan, J. C., Lee, S., \& Good, B. (2007). Culture and stigma: Adding moral experience to stigma theory. Social Science \& Medicine, 64(7), 15241535. http://doi.org/10.1016/j.socscimed.2006.11.013
Field Code Changed

Field Code Changed 